\title{
GROWTH IN PARTIALLY DEFOLIATED STRAWBERRY PLANTS CULTIVATED IN THE TROPICAL HIGHLANDS
}

\section{CRECIMIENTO EN PLANTAS DE FRESA PARCIALMENTE DEFOLIADAS CULTIVADAS EN LOS ALTIPLANOS TROPICALES}

\author{
Fánor Casierra-Posada ${ }^{1^{*}}$, Israel D. Torres ${ }^{2}$, Donald H. Riascos-Ortíz ${ }^{3}$ \\ ${ }^{1}$ I.A. Ph.D. Pedagogical and Technological University of Colombia UPTC, Faculty of Agricultural Sciences. Plant Ecophysiology \\ Research Group. Avenida Central del Norte, Tunja / Colombia. *Corresponding author: fanor.casierra@uptc.edu.co, ${ }^{2}$ I.A., \\ UPTC; ${ }^{3}$ I.A., M.Sc. UPTC.
}

Rev. U.D.C.A Act. \& Div. Cient. 15 (2): 349 - 355, 2012

\section{SUMMARY}

Plants may undergo partial defoliation due to natural or accidental factors. The present study presents the results of an experiment to determine the effects of partial defoliation on the growth of strawberry plants (Fragaria $\times$ ananassa Duch. cv. 'Chandler') in Tunja, Colombia. Three defoliation levels were applied to plants after transplanting: 38\% defoliation, $67 \%$ defoliation, and a control without defoliation. Water uptake, dry matter distribution among different plant organs, leaf area, and total dry weight were measured. Using this information it was possible to calculate leaf area ratio (LAR), leaf weight ratio (LWR), absolute and relative growth rates, and water use efficiency. All variables evaluated showed reduced values as a result of defoliation, which indicates that strawberry plants are sensitive to defoliation levels above $38 \%$ and show severely compromised growth as a result.

Key words: Fragaria $\times$ ananassa, dry matter, leaf area, growth analysis

\section{RESUMEN}

Debido a factores naturales o accidentales, las plantas pueden experimentar defoliación parcial. Se presentan los resultados de un experimento orientado a determinar el efecto de la defoliación parcial sobre el crecimiento de plantas de fresa (Fragaria $\times$ ananassa Duch. cv. 'Chandler'), realizado en Tunja, Colombia. Se aplicaron tres niveles de defoliación, de 0 (control), 38 y $67 \%$, desde el inicio de la brotación de hojas luego del transplante. Se determinó la toma de agua, la distribución de materia seca en los diferentes órganos, el área foliar y el peso seco total. Con esta información, se calculó la relación de área foliar, la relación de peso foliar, las tasas de crecimiento absoluto y relativo, así como también la eficiencia en el uso del agua. Todas las variables evaluadas mostraron valores reducidos como consecuencia de la defoliación, lo que indica que las plantas de fresa son sensibles a niveles de defoliación por encima de $38 \%$, con lo cual el crecimiento se ve seriamente comprometido.

Palabras clave: Fragaria $\times$ ananassa, materia seca, área foliar, análisis del crecimiento

\section{INTRODUCTION}

Cultivated plants are exposed to natural factors such as hail, wind, insect attacks, and disease, as well as human accidents like the incorrect application of herbicides or damage caused by machinery, all of which can cause different types of defoliation (Muro et al. 2000). Defoliation causes a reduction in growth, in productivity, and in the quality of the harvested product (Albregts et al. 1992). The degree of reduction in quality and growth depends on the nature of the defoliation and the development phase of the crop at defoliation (Muro et al. 2000).

Defoliation in ribwort plantain (Plantago lanceolata) showed to have negative effects on root growth, on biomass of inflorescences, and on leaf nitrogen content. In fact, while dry matter in roots was reduced as a result of defoliation, leaf production was not affected. Shifting biomass distribution from roots to leaf production is thus seen as a mechanism for compensating reduced leaf area (Pietikäinen et al. 2009). Kiwi, Actinidia deliciosa, is affected by defoliation presenting lower fruit weight, starch concentration in branches and 
trunk bark, and total soluble carbohydrates in branches (Cruz-Castillo et al. 2010).

In strawberry plants, defoliation not only affects growth but also fruit quality. In the Flamenco cultivar, defoliation did not affect production quantity of marketable fruits, though there was a modification in the production peak (Whitehouse et al. 2009). But this was the exception; the majority of cultivars evaluated by these authors reduced total production as a consequence of defoliation. In the Camarosa cultivar the highest production and growth were achieved in intact strawberry plants as compared to defoliated plants (Mohamed, 2002). Plant size at the beginning and middle of the season and fruit size are also all affected when strawberry plantlets are subjected to severe defoliation in the moment of transplanting (Albregts et al. 1992).

Strawberry is an important crop in Colombia, grown mainly in the cooler highland regions. Over the past 20 years, both area planted and total production of strawberry in Colombia have experienced massive increases, achieving levels of some 1300 ha and 40000 tons in 2010. The most important departments in terms of strawberry production are Cundinamarca, Antioquia, and Norte de Santander (Agronet, 2012).

While Whitehouse et al. (2009) suggest that more studies are needed to evaluate whether defoliation might be a useful agronomic tool in order to avoid high temperatures that reduce flowering in many varieties, Richards (1993) mentioned that it is necessary to learn more about how physiological functions are altered in defoliated plants in order to understand their reaction and recovery after such a disturbance.

The present study thus aimed to evaluate growth in partiallydefoliated strawberry plants of the 'Chandler' cultivar grown in the tropical high plains.

\section{MATERIALS AND METHODS}

The experiment was carried out in greenhouse conditions at the Pedagogical and Technological University of Colombia in Tunja, located at $5^{\circ} 33^{\prime} 56,66^{\prime \prime} N$ and $73^{\circ} 21^{\prime} 23,68^{\prime \prime} \mathrm{W}$ coordinates, at an altitude of 2691 meters above sea level. Inside the greenhouse average temperature was $16.2^{\circ} \mathrm{C}$, with $71.8 \%$ relative humidity and a photosynthetic photon flow density of $521.7 \mu \mathrm{mol} \mathrm{m} \mathrm{m}^{-2}$. Light intensity in the greenhouse was low due to a number of factors. Tunja tends to have overcast skies due to its highland equatorial climate. This was even more the case in the year when the experiment was carried out, as El Niño/La Niña oscillations made for even more rain than usual. Finally, the greenhouse at the UPTC University underwent an ill-advised overhaul some years ago in which the glass was painted white to limit heat buildup. For all of these reasons, the present experiment occurred under relatively low light conditions.

The planting material used were plantlets from 'Chandler' variety strawberries (Fragaria $\times$ ananassa Duch.) that had been exposed to temperatures of $6 \pm 2^{\circ} \mathrm{C}$ during two weeks prior to planting. This treatment was intended to overcome bud dormancy and thus coordinate sprouting. At the time of transplanting 20 plantlets were set aside to assess leaf area and dry weight as a baseline for final growth measurements.

Plantlets were placed in four-liter glass containers filled with a nutrient solution with the following composition in $\mathrm{mg} \mathrm{L}^{-1}$; nitrate nitrogen 40.3; ammonium nitrogen 4.0; phosphorus 20.4; potassium 50.6; calcium 28.8; magnesium 11.4; sulfur 1.0; iron 1.12; manganese 0.112 ; copper 0.012 ; zinc 0.0264 ; boron 0.106 ; molybdenum $1.2 \mathrm{E}^{-3}$, and cobalt $3.6 \mathrm{E}^{-4}$. To avoid hypoxic root conditions, air was constantly bubbled into the nutrient solution.

Upon the appearance of each leaf, one or two of its leaflets were removed, thus achieving defoliation of $38 \%$ or $67 \%$ respectively. Control plants grew intact, with no leaflets removed. This procedure was carried out once every two weeks on recently-emerged leaves.

The experiment lasted seven months, at the end of which dry weight of the different plant organs (dried in an $80^{\circ} \mathrm{C}$ oven) was measured. Leaf area was determined with a Li-cor 3000A analyzer (LI-COR Biosciences, USA). With this information it was possible to calculate the leaf area ratio (LAR), leaf weight ratio (LWR), specific leaf area, root/shoot ratio, harvest index (harvestable dry matter), absolute growth rate, and relative growth rate, based on the procedures outlined by Hunt (1990). Net assimilation rate was calculated based on the methodology reported by Vernon \& Allison (1963). Every week the amount of water missing from the containers was measured, and taken as the water consumed by the plant. Water use efficiency (WUE) was calculated as the amount of dry matter produced per liter of evapotranspired water (Briggs \& Shantz, 1914).

The experiment had a totally-randomized one-factor design in which plants underwent $38 \%$ and $67 \%$ defoliation (one or two leaflets removed per leaf, respectively). The results of these treatments were compared to control plants that were not subjected to defoliation. Each treatment consisted in 20 plants, and analyses were performed individually for each plant. In this way each plant was taken as a repetition $(N=20)$. The data obtained was subjected to a classical variance analysis $(p<0.05)$ and Tukey's range test using the program PASW (Predictive Analytics Software) version 18.0.0 (30-07-2009; IBM Corporation, Somers - USA). 


\section{RESULTS AND DISCUSSION}

Intact, non-defoliated plants developed a leaf area of $1033.94 \mathrm{~cm}^{2}$ on average, while plants subjected to defoliation treatments presented leaf area values 636.86 and $332.82 \mathrm{~cm}^{2}$, giving defoliation levels of $38 \%$ and $67 \%$ as opposed to the $33 \%$ and $67 \%$ that might be expected from the removal of a third or two thirds of leaflets. The leaf area values obtained under different treatments represent reference values to better understand the other parameters evaluated in this study.

Reekie (Reekie, J.Y., Wageningen, Holanda: personal communication) found that early removal of leaves at transplanting reduced the leaf area and plant size necessary for strawberry plants to begin flower formation, and thus cultivars 'Sweet Charlie' and 'Camarosa' experienced delayed entry in production. By the same token, early removal of $75 \%$ of leaf area was excessive and reduced plant vigor. The same trend applied to the results of the present study, since treatments with $38 \%$ and $67 \%$ defoliation reduced fruit number per plant by $12.0 \%$ and $28.4 \%$, respectively, which suggests a depressive effect of defoliation on flower induction.

The root/shoot ratio and specific leaf area showed no significant difference between treatments. In leaf area ratio highly significant differences were found $(p<0.01)$ between control plants and those subjected to $67 \%$ defoliation, but not between control plants and 38\% defoliated plants (Table 1). In this parameter, removal of $67 \%$ of leaf area led to a reduction of $18.6 \%$ in the value of leaf area ratio as compared to control plants. Leaf weight ratio also acted similarly to the rest of the variables analyzed, since it diminished with increasing defoliation intensity, with statistically significant differences. The removal of $38 \%$ and $67 \%$ of leaf area induced a reduction of $13.1 \%$ and $30.6 \%$ in the value of leaf weight ratio as compared to control plants (Table 1).
Water consumption showed statistically significant difference $(p<0.01)$ and decreased with defoliation intensity. Average values encountered for water uptake were reduced $31.2 \%$ and $51.3 \%$ compared to control plants in plants undergoing $38 \%$ and $67 \%$ defoliation, respectively.

The reduction in water consumption in defoliated plants was the result of lower area for transpiration. On this topic, Hicklenton \& Reekie (2002) and Reekie (Reekie, J.Y.: personal communication) found that in partially defoliated strawberry plants, water loss was considerably lower than in nondefoliated plants, while stomatal conductance was greater in plants with intact foliage. On the other hand, in the present study it was observed that there was no difference in LAR value between control plants and 38\% defoliated plants. This is possibly due to the compensation mechanism through which the assimilate export from source organs is increased and preferentially allocated to growing sink organs in the aerial part of the plants, which reestablishes photosynthesis in leaves after defoliation (Richards, 1993). This mechanism initiates mere hours after defoliation. Furthermore, when actively growing tissues are removed, available assimilates can accumulate in other sink tissues.

No statistically significant difference was found for net assimilation rate values. Absolute growth values and relative growth values showed similar tendencies, and their average value was reduced as defoliation intensified, with statistically significant differences $(\mathrm{p}<0.01)$. Absolute growth rate was reduced $35.5 \%$ and $61.9 \%$ as compared to control plants in plants suffering $38 \%$ and $67 \%$ defoliation, respectively. In the same way, relative growth rate was reduced by $17.7 \%$ and $38.5 \%$, respectively.

The differences in relative growth rate can be the consequence of specific demands imposed on plants under different crop conditions. When plants are subjected to conditions that cause partial defoliation, there is an instantaneous reduction

Table 1. Growth indices, water uptake, and leaf area found in strawberry plants (Fragaria x ananassa cv. 'Chandler') subjected to partial defoliation $(N=20)$.

\begin{tabular}{|c|c|c|c|c|c|c|c|}
\hline $\begin{array}{c}\text { Defoliation } \\
(\%)\end{array}$ & $\begin{array}{c}\text { Leaf area ratio } \\
\left(\mathrm{m}^{2}\right)\end{array}$ & $\begin{array}{c}\text { Leaf weight ratio } \\
\left(\mathrm{g} \mathrm{g} \mathrm{g}^{-1}\right)\end{array}$ & $\begin{array}{c}\text { Absolute growth } \\
\text { rate } \\
\left(\mathrm{g} \mathrm{d}^{-1}\right)\end{array}$ & $\begin{array}{c}\text { Relative growth } \\
\text { rate } \\
\left(\mathrm{g} \mathrm{g}^{-1} \mathrm{~d}^{-1}\right)\end{array}$ & $\begin{array}{c}\text { Water uptake } \\
(\mathrm{L})\end{array}$ & $\begin{array}{c}\text { Leaf area } \\
\left(\mathrm{cm}^{2}\right)\end{array}$ \\
\hline Control & $2.1 \mathrm{E}^{-3} \mathrm{a}$ & $0.18 \mathrm{a}$ & $0.21 \mathrm{a}$ & $7.5 \mathrm{E}^{-3} \mathrm{a}$ & $11.09 \mathrm{a}$ & $1033.94 \mathrm{a}$ \\
\hline 38 & $2.1 \mathrm{E}^{-3} \mathrm{a}$ & $0.16 \mathrm{~b}$ & $0.14 \mathrm{~b}$ & $6.1 \mathrm{E}^{-3} \mathrm{~b}$ & $7.63 \mathrm{~b}$ & $636.86 \mathrm{~b}$ \\
\hline 67 & $1.7 \mathrm{E}^{-3} \mathrm{~b}$ & $0.12 \mathrm{c}$ & $0.08 \mathrm{c}$ & $4.6 \mathrm{E}^{-3} \mathrm{c}$ & $5.39 \mathrm{c}$ & $332.82 \mathrm{c}$ \\
\hline
\end{tabular}


in photosynthesis (Richards, 1993). Furthermore, with reduced carbon gain, the translocation of carbon from source tissues is slowed, as is charging activity in the phloem. This explains the reduction in absolute and relative growth rates found in the present study, seeing as these growth variables are calculated based on the dry mass accumulated over time, which is drastically diminished as a result of defoliation. In addition, Richards (1993) reported that the immediate effects of defoliation depend mainly on its intensity, and are related principally to the degree of photosynthesis reduction and carbon uptake in the entire plant.

In relation to the distribution of dry matter in different plant organs, highly significant differences were found $(p<0.01)$ in all organs, except for the dry matter assigned to roots and flowers. While the proportion of dry matter assigned to leaves and petioles decreased with more intense defoliation, dry matter accumulation in crown and fruits increased (Figure 1).

Through various studies undertaken on C 3 and C4 plants tolerant to defoliation, it has been shown that root elongation stops in the span of 24 hours after removal of over $40 \%$ of leaf area, and also that the ratio between photosynthesis and transpiration is drastically reduced. Root respiration under these conditions is rapidly reduced, but the magnitude of this reduction is lower in roots than in aerial parts of the plant. On the other hand, nutrient absorption is also rapidly reduced after defoliation. The speed with which root respiration and nutrient uptake are reduced depends on the magnitude of the defoliation (Richards, 1993). Despite these findings, in the present study dry matter accumulation in strawberry roots did not show significant differences. This corresponds to the findings of Richards (1993), who suggests that carbon assignation to the roots can continue after defoliation, since roots are strong sinks in some plants.

It must be kept in mind that growth and productivity in strawberry plants depends in large part not only on dry matter formation but also on its distribution in different plant organs (Reekie, J.Y.: personal communication). Defoliation of strawberry plants in the present study represented a challenge to the functions of growth and fruit production under conditions of reduced leaf area and the low illumination found in the greenhouse for the aforementioned reasons $\left(521.7 \mu \mathrm{mol} \mathrm{m}{ }^{-2} \cdot \mathrm{s}^{-1}\right)$. Hence defoliated plants had to modify their pattern of dry matter assignation. Plants naturally adjust their development to what the environment offers, in order to assure survival and production (Bazzaz \& Grace, 1997). In response to the availability of resources, the plant can assign more dry matter to the roots when light is limiting, or to leaves and petioles when water or nutrients are limiting. Hence a plant will be successful if it develops a morphology that allows it to maximize metabolism and physiological functions (Reekie, J.Y.: personal communication).

In everbearing cultivars of strawberry such as 'Chandler', production is determined by the number of crowns per plant and by the duration of the production period (Wilson \& Dixon, 1988), for which reason in the present study it was found that plants exposed to defoliation assigned more dry matter to fruits and crowns. Nevertheless, this reassignment of dry matter to fruits and crowns in defoliated plants was not sufficient to attain a substantial increase in the weight of fruit produced. Compared to control plants, total fruit production was $24.4 \%$ and $48.7 \%$ lower in plants subjected to $38 \%$ and $67 \%$ leaf area reduction, respectively, because defoliation drastically reduced fruit size. Darnell \& Hancock

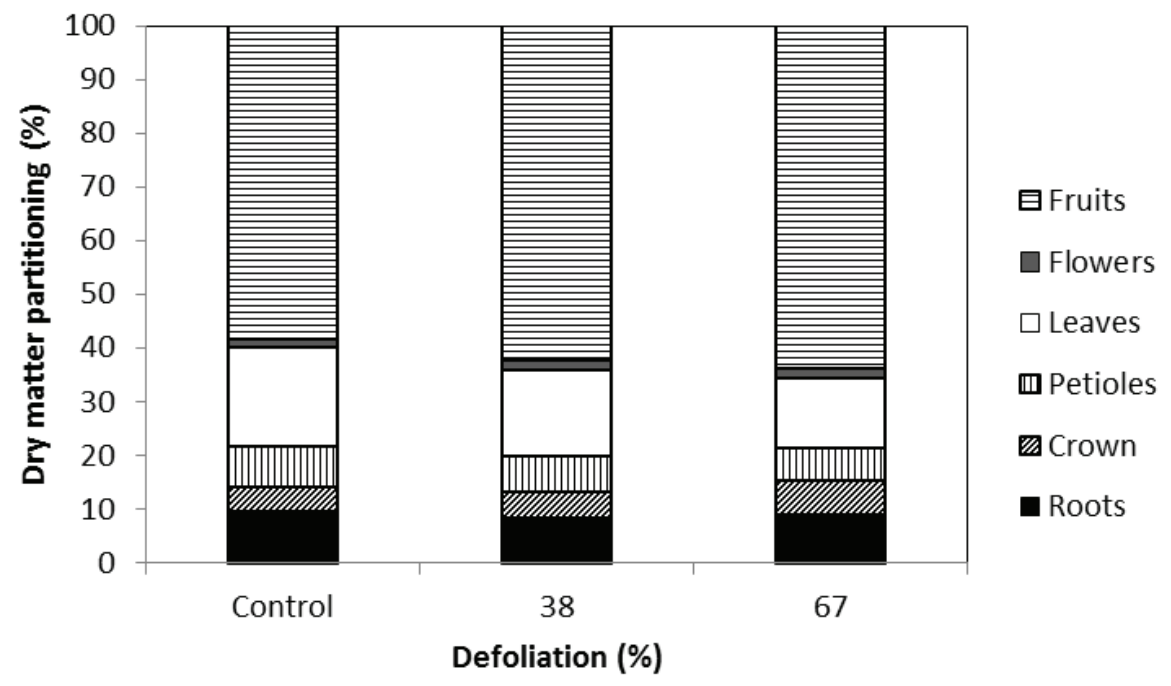

Figure 1. Dry matter distribution in partially-defoliated strawberry plants (Fragaria x ananassa Duch.) cv. 'Chandler' $(\mathrm{N}=20)$ 
(1996) reported that the optimal dry matter distribution in strawberries, as well as a high rate of $\mathrm{CO}_{2}$ assimilation, are determining factors for high fruit production. These conditions were not fulfilled in the present study, since both total dry matter per plant and total fruit production were negatively affected by defoliation. This suggests alterations in the rates of photosynthesis and respiration that limited both growth and fruit production.

The increase in dry matter allocation to fruits as leaf area decreased can be seen as a consequence of the competition between vegetative and reproductive organs, since it has been reported that in the strawberry cultivar 'Tribute' leaf formation is limited by fruiting (Schaffer et al. 1986). In cultivar 'Elsanta', Pérez de Camacaro et al. (2002) found that the greatest vegetative growth occurred after fruiting. Thus under the vigor-limiting conditions created by defoliation, fruits should represent a stronger sink than leaves, attracting more photosynthates in this way. Some authors have demonstrated the relationship between leaf area and fruit production, and that this relationship influences flavor, as higher leaf area leads to greater total soluble solids (Carlen et al. 2007). However, this trend is not the same in all cultivars or in all locations (Crespo et al. 2010).

Dry weight per plant was drastically reduced as a consequence of defoliation. Treatments of $38 \%$ and $67 \%$ defoliation reduced this value by 34.1 and $58.6 \%$, respectively, in relation to control plants, with highly significant differences $(\mathrm{p}<0.01)$ (Figure 2).
Reduction in total dry matter production was due to the loss of vigor of strawberry plants as a result of defoliation. In fact, defoliation negatively affected growth and yield factors, and as a result total dry weight production per plant was seriously compromised. To the contrary, Anten \& Ackerly (2001) showed that in partially-defoliated palm plants there was an increase in light interception by the fronds and an increase in the unit leaf rate, which allowed an increase in photosynthetic rate. The increase in unit leaf rate is considered to be a compensatory mechanism to make up for growth losses caused by defoliation (Anten et al. 2003). According to these authors, the physiological changes caused by defoliation, which increase unit leaf rate and photosynthesis, are important for improving growth and dry matter production. On the other hand, Kerkhoff et al. (1988) found an increase in net photosynthesis in strawberry plants after partial defoliation, due to a compensation mechanism in the remaining plant tissue. Nevertheless, Morrison \& Reekie (1995) specify that defoliation does not always lead to increases in photosynthesis rate.

There was no statistically-significant difference found between control plants and those undergoing $38 \%$ defoliation in terms of water use efficiency (WUE), but there was a difference between these two treatments and the $67 \%$ defoliated plants $(p<0.01)$, with a decrease of $14.8 \%$ in the latter group as compared to the control plants (Figure 3).

Reduction in leaf area diminished both water uptake and dry matter production in the plants of the present study,

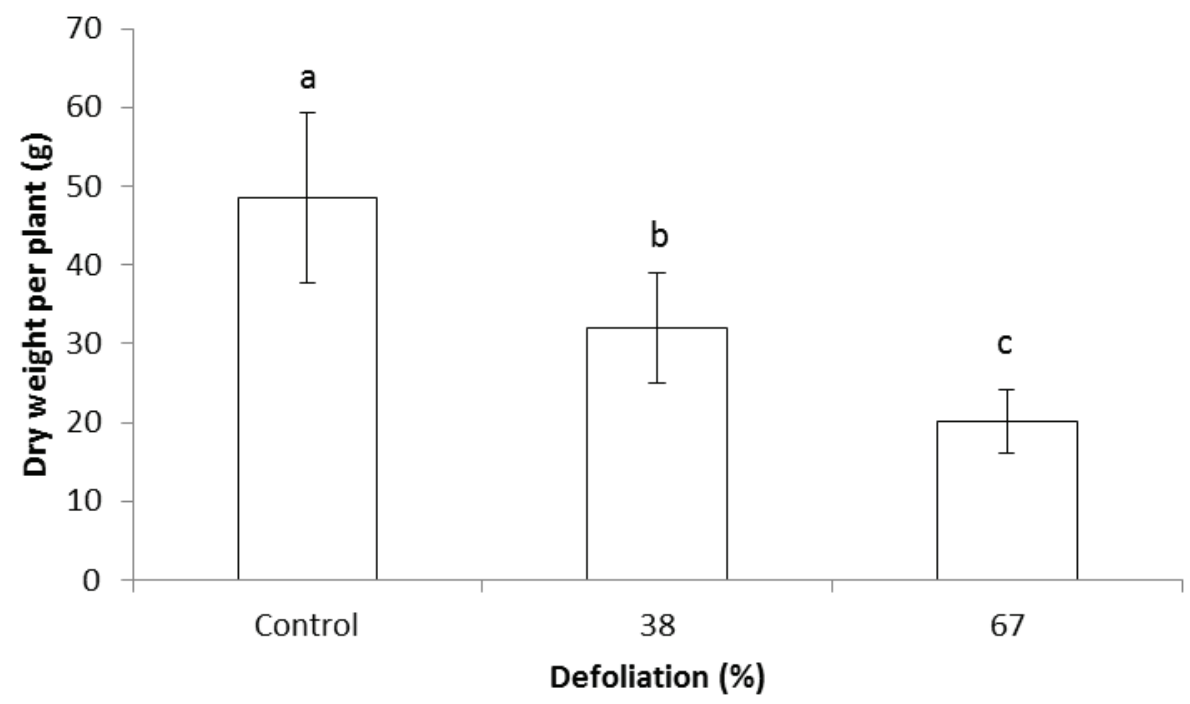

Figure 2. Dry weight per plant in partially-defoliated strawberry (Fragaria x ananassa Duch.) cv. 'Chandler' (N=20). Averages accompanied by the same letter showed no statistically significant difference according to the Tukey range test $(p<0.01)$. 
which follows the affirmations of Khan et al. (2002) that photosynthetic efficiency in water use decreased in partiallydefoliated mustard plants. Furthermore, partial defoliation triggers the emergence of new leaves to make up for the loss in leaf area. These new leaves have a different saturation point compared with the older ones, which have lower stomatal conductance due to lower $\mathrm{CO}_{2}$ provision to chloroplasts. This lowers net photosynthesis, which ultimately causes a reduction in biomass production. These findings corroborate those of Hicklenton \& Reekie (2002), who found that in partially-defoliated strawberry plants, both water loss and stomatal conductance were reduced in comparison to intact plants. Thus the alteration in stomatal conductance, water loss, and photosynthesis rate as a result of defoliation negatively affected WUE of strawberry in the present study.

Defoliation at the levels evaluated caused a decrease in growth in 'Chandler' variety strawberry plants directly proportional to the intensity of defoliation. Nevertheless, in partially-defoliated plants there was a modification in the pattern of dry matter allocation as defoliation intensified, with less dry matter assigned to petioles and leaves, and more dry matter destined for crowns and fruits. This suggests a mechanism developed by strawberry plants exposed to partial defoliation to compensate the loss of leaf area and thus guarantee survival.

Acknowledgments: The team gratefully acknowledges the generous support of the Research Directorate (Dirección de Investigaciones - DIN) of the Pedagogical and Technological
University of Colombia (UPTC) for providing us with the funding and opportunity to conduct this research project. A very special thanks goes out to the members of the Research Group in Plant Ecophysiology (Grupo Ecofisiología Vegetal) of the Faculty of Agricultural Sciences of the UPTC. Conflict of interest: The manuscript was prepared and reviewed with the participation of all authors, who declare the absence of interest conflicts that jeopardizes the validity of the results presented.

\section{BIBLIOGRAPHY}

1. AGRONET, 2012. Producción nacional por producto: Fresa. Report. Consulted online August 29, 2012 at: http://www.agronet.gov.co/agronetweb1/ Estad\%C3\%ADsticas/ReportesEstad\%C3\%ADsticos. aspx

2. ALBREGTS, E.E.; HOWARD, C.M.; CHANDLER C.K. 1992. Defoliation of strawberry transplants for fruit production in Florida. HortSci. 27(8):889-891.

3. ANTEN, N.P.R.; ACKERLY, D.D. 2001. Canopy-level photosynthetic compensation after defoliation in a tropical understory palm. Funct. Ecol. 15:252-262.

4. ANTEN, N.P.R.; MARTÍNEZ-RAMOS, M.; ACKERLY, D.D. 2003. Defoliation and growth in an understory palm: quantifying the contributions of compensatory responses. Ecol. 84:2905-2918.

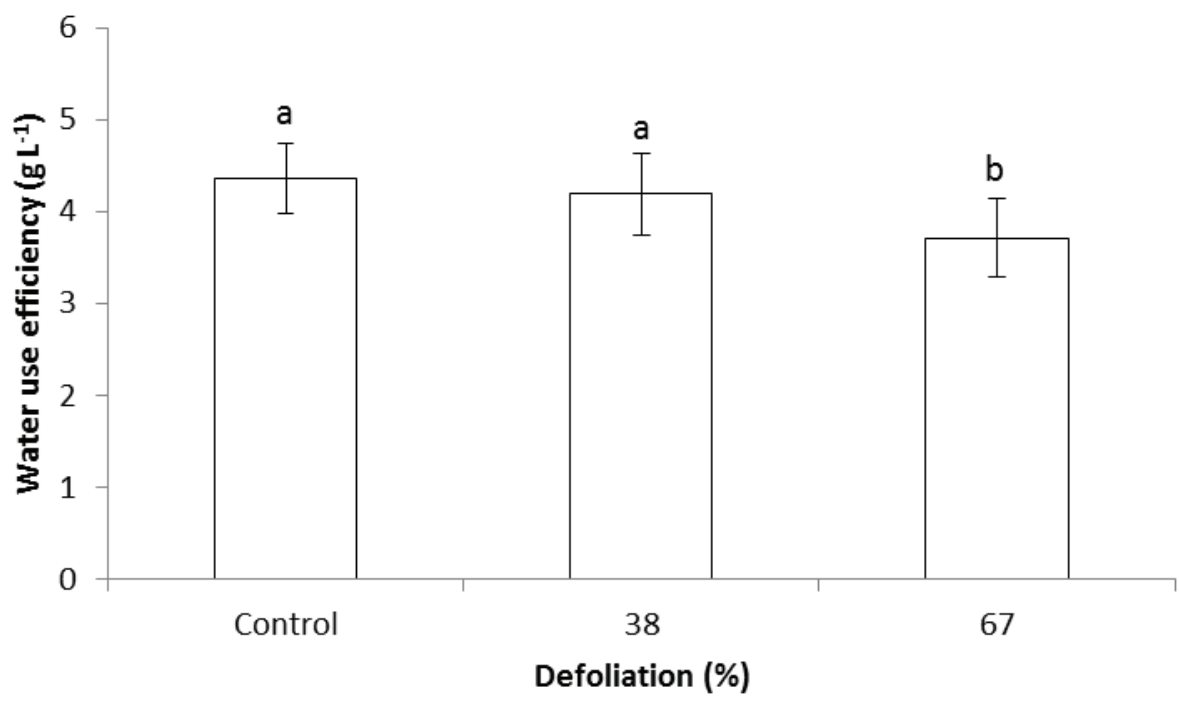

Figure 3. Water use efficiency in partially-defoliated strawberry plants (Fragaria x ananassa Duch.) cv. 'Chandler' $(\mathrm{N}=20)$. Averages accompanied by the same letter showed no statistically significant difference according to the Tukey range test $(\mathrm{p}<0.01)$. 
5. BAZZAZ, F.A.; GRACE, J. 1997. Plant Resource Allocation. Academic Press, San Diego, CA. 303p.

6. BRIGGS, L.J.; SHANTZ, H.L. 1914. Relative water requirements of plants. Research. 3:1-63.

7. CARLEN, C.; POTEL A.M.; ANÇAY, A. 2007. Influence of leaf/fruit ratio of strawberry plants on the sensory quality of their fruits. Acta Hort. 761:121-126.

8. CRESPO. P.; BORDONABA, J.G.; TERRY, L.A.; CARLEN, C. 2010. Characterization of major taste and health-related compounds of four strawberry genotypes grown at different Swiss production sites. Food Chem. 122:16-24.

9. CRUZ-CASTILLO, J.G.; WOOLLEY, D.J.; FAMIANI, F. 2010. Effects of defoliation on fruit growth, carbohydrate reserves and subsequent flowering of 'Hayward' kiwifruit vines. Sci. Hort. 125:579-583.

10. DARNELL, R.L.; HANCOCK, J.F. 1996. Balancing vegetative and reproductive growth in strawberry. Proc. IV North American Strawberry Conference. p.144-150.

11. HICKLENTON, P.R.; REEKIE, J.Y.C. 2002. The nursery connection: exploring the links between transplant growth and development, establishment, and productivity. In: Hokanson, S.; Jamieson, A. (eds). Strawberry research to 2001. Alexandria: ASHS. p.136-146.

12. HUNT, R. 1990. Basic growth analysis. UbWin IMAN. Londres. 112p.

13. KHAN, N.A.; KHAN, M.; ANSARI, H.R.; SAMIULLAH. 2002. Auxin and defoliation effects on photosynthesis and ethylene evolution in mustard. Sci. Hort. 96:4351

14. KERKHOFF, K.L.; WILLIAMS, J.M.; BARDEN, J.A. 1988. Net photosynthetic rates and growth of strawberry after partial defoliation. HortSci. 23:1086-1088.

15. MOHAMED, F.H. 2002. Effect of transplant defoliation and mulch color on the performance of three strawberry cultivars grown under high tunnel. Acta Hort. 567:483-485.

16. MORRISON, K.D.; REEKIE, E.G. 1995. Pattern of defoliation and its effect on photosynthetic capacity in Oenothera biennis. J. Ecol. 83:759-767.

17. MURO, J.; IRIGOYEN, I.; LAMSFUS, C.; MILITINO, A.F. 2000. Effect of defoliation on garlic yield. Sci. Hort. 86:161-167.

18. PIETIKÄINEN, A.; MIKOLA, J.; VESTBERG, M.; SETÄLÄ, H. 2009. Defoliation effects on Plantago lanceolata resource allocation and soil decomposers in relation to AM symbiosis and fertilization. Soil Biol. Biochem. 41:2328-2335.

19. PÉREZ DE CAMACARO, M.E.; CAMACARO, G.J.; HADLEY, P.; BATTEY, N.H.; CAREW, J.G. 2002. Pattern of growth and development of the strawberry cultivars Elsanta, Bolero and Everest. J. Am. Soc. Hort. Sci. 127:901-907.

20. RICHARDS, J.H. 1993. Physiology of plants recovering from defoliation. Proc. XVII international grassland congress. Palmerston North, N.Z. p. 85-94.

21. SCHAFFER, B.; BARDEN, J.A.; WILLIAMS, J.M. 1986. Net photosynthesis, dark respiration, stomatal conductance, specific leaf weight, and chlorophyll content of strawberry plants as influenced by fruiting. J. Am. Soc. Hort. Sci. 111:82-86.

22. VERNON, A.J.; ALLISON, J.C.S. 1963. A method of calculating net assimilation rate. Nature. 200:814.

23. WILSON, F.; DIXON, G.R. 1988. Strawberry growth and yield related to plant density using matted row husbandry. J. Hort. Sci. 63:221-227.

24. WHITEHOUSE, A.B.; JOHNSON, A.W.; SIMPSON, D.W. 2009. Manipulation of the production pattern of everbearing cultivars by defoliation treatments. Acta Hort. 842:773-776

Received: 28 February 2012

Accepted: 3 September 2012 